\title{
REVIEW
}

\section{Parasympathetic nervous system dysfunction in primary Siögren's syndrome}

A Hočevar, M Tomšič, S Praprotnik, M Hojnik, T Kveder, B Rozman

Ann Rheum Dis 2003;62:702-704

In the past sicca syndromes were attributed to destruction of glandular tissue. It is now thought that cytokines, autoantibodies, and parasympathetic nervous system dysfunction all have an important role in the xerostomia and xerophthalmia in Siögren's syndrome.

W e recently followed the case of a middle aged woman who had sicca syndromes, verified by positive Schirmer's test, fluorescein staining of the cornea and conjunctiva, and abnormal salivary gland scintigraphy. She was anti-Ro and anti-La positive, but had no substantial lymphocytic infiltration on a small gland salivary biopsy. After an episode of viral (probably herpetic) encephalitis her sicca symptoms disappeared, both subjectively and according to clinical tests. This prompted us to review and summarise experimental and clinical data for the pathogenesis of xerostomia and xerophthalmia in Sjögren's syndrome.

Primary Sjögren's syndrome (primary SS) is a chronic inflammatory autoimmune disease characterised by lymphocytic infiltration of the exocrine glands, resulting in dry eyes and dry mouth. The aetiology is unknown and the prevalence uncertain. ${ }^{12}$ The diagnostic criteria, proposed by the American-European Consensus group, consist of six items (subjective dry eyes, subjective dry mouth, objective ocular involvement, abnormal focus score in lower lip biopsy, objective tests of oral involvement, and presence of anti-Ro or anti-La). At least four items must be positive to establish the diagnosis of primary SS, including the demonstration of anti-Ro or anti-La or a characteristic minor salivary gland biopsy. ${ }^{3}$ Apart from sicca symptoms due to the glandular affection, various extraglandular manifestations may develop, including central and peripheral nervous system lesions. ${ }^{4}$

Autonomic nervous system dysfunction may be an unrecognised feature of primary SS. The experimental findings and results of clinical studies pertinent to this issue are inconsistent. Andonopoulous et al found the symptoms of autonomic dysfunction in about one half of the investigated patients, while functional testing gave abnormal results in two thirds of them. Barendregt et al reported no differences in the sympathetic and parasympathetic control functions, comparing the cardiovascular regulation between patients with primary SS and healthy controls, and also no correlation between the results of clinical tests for parasympathetic dysfunction and decreased salivation or tearing. ${ }^{6-8}$ A diminished or absent microvascular response to the intracutaneous application of the cholinergic agonist carbachol was demonstrated in half ( 11 of 22 ) of the patients with primary SS examined by Kovács et al. However, they did not detect any differences in the occurrence of specific organ manifestations, including autonomic, the severity of glandular impairment, and laboratory findings, between the patients responding and not responding to carbachol. ${ }^{9}$

Xerostomia and xerophthalmia have, until recently, been explained by progressive inflammatory infiltration and destruction of the exocrine glands, as histological changes of the glands were correlated with the salivary flow rates. ${ }^{10}$ In general, patients with the highest focus score in the minor salivary gland biopsy also had the most severe reduction in the salivary gland function. ${ }^{11}$ Repeated biopsies also showed time dependent aggravation of sialoadenitis. ${ }^{12}$

However, in patients with primary SS the focus score did not always parallel the sialometric result. ${ }^{13}$ Furthermore, in patients with other connective tissue diseases no signs of a decreased salivary function were reported, despite inflammatory foci in the minor salivary glands. ${ }^{14}$ All these findings point to an additional mechanism implicated in the impaired salivary secretion in primary SS. Affection of the autonomic, mainly parasympathetic nervous system, which controls the exocrine secretion, may be responsible for the glandular dysfunction, resulting in diminished salivation and tears. ${ }^{15} 16$

Lachrymal and salivary glands are richly innervated. Parasympathetic nerve endings, containing acetylcholine (ACh), vasoactive intestinal peptide, and other neurotransmitters, send signals predominantly to the glandular tissues. Their stimulation, mediated through the muscarinic cholinergic receptors (MAChR), results in the secretion of fluid and ions. Impulses originate in the autonomic nuclei in the medulla oblongata, where peripheral afferent signals from the mucous surfaces and information from the central autonomic network integrate. ${ }^{4}$ Vasoactive intestinal peptide, as a trophic stimulus, is believed to regulate the replication and growth of the acinar cells, ${ }^{17}$ while adrenergic nerves send signals to blood vessels and are therefore responsible for protein secretion. Among the five different types of muscarinic receptors, M3AChR predominate in

Abbreviations: $\mathrm{ACh}$, acetylcholine; $\mathrm{CAN}$, central autonomic network; MAChR, muscarinic cholinergic receptors; NO, nitric oxide; NOD, non-obese diabetic; SS, Siögren's syndrome 
the lachrymal glands, whereas equal amounts of M3AChR and MlAChR are present in the salivary glands. ${ }^{18} \mathrm{M} 3 \mathrm{AChR}$ are also found in blood vessels, contributing to vasodilatation via nitric oxide (NO), in sweat glands, intestinal and urinary tract smooth muscles, iris sphincter, and other organs under the autonomic nervous system control. ${ }^{16}$

\section{"Regulation of salivation and tear formation can occur in the central autonomic nervous system or peripherally"}

Theoretically, disturbances of the autonomic nervous function responsible for diminished salivation and tear formation can originate in the central autonomic nervous system, or peripherally, being localised either in peripheral autonomic nerve fibres, or synapses of nerve endings with glandular cells, or the effector cells themselves.

\section{CENTRAL AUTONOMIC NETWORK}

The central autonomic network (CAN) consists of functional units in multiple areas, which control autonomic functions in tonic, reflexive, and adaptive manners. They receive and integrate visceral, humoral, and environmental information. ${ }^{19}$ There is no firm evidence for the involvement of CAN in primary SS, either in animal models or in humans. However, certain drugs (namely, antidepressive drugs, the antihypertensive drug clonidine) decrease salivation, which is a side effect exerted on the central nervous system. ${ }^{20}$ This suggests that CAN has an important role in parasympathetic dysfunction, including hyposalivation in primary SS. Furthermore, patients with Alzheimer's disease have decreased salivary flow rates without any focal mononuclear infiltrates in the salivary glands. ${ }^{21}$ Central autonomic dysfunction is also a proposed pathogenetic mechanism in patients with fibromyalgia, who have hyposalivation. ${ }^{4}$

\section{PERIPHERAL NERVOUS SYSTEM Peripheral nerve fibres}

Parasympathetic nerves themselves may be the next possible site of disturbance. In the regions of focal lymphocytic infiltrates, only a few neural axons were detected by immunohistological methods, which identify neural axonal markers and neural peptides. ${ }^{22}$ In contrast, they were preserved in the areas with residual normal acini, but did not seem to compensate for the loss of salivation and tear formation..$^{23}$ Additionally, some reports favour the suggestion of unaltered innervation. Zoukhiri et al demonstrated that the density and patterns of parasympathetic, sympathetic, and sensory innervation in the non-inflamed acinar tissue in the MRL/MP-Fas-lpr/lpr murine model of SS were indistinguishable from those in age matched control mice. ${ }^{24}$ Furthermore, Kovács et al were unable to confirm the denervational aetiology of the autonomic nervous system disturbance at the level of peripheral nerve fibres by studying the effect of carbachol-an M3AChR agonistintroduced into the skin of 22 patients with primary SS. The extent of vasodilatation was significantly lower in patients with primary SS than in controls, supporting the hypothesis that the dysfunction existed at the receptor or postreceptor level. ${ }^{9}$

\section{Defects in neural transmission in synapses}

As already mentioned, ACh is the main neurotransmitter released from the parasympathetic nerve endings into the synaptic cleft. Its action is mediated through the binding to muscarinic receptors on the effector cells. In primary SS, an increased number of M3AChR were found in the patients' glands, which may be secondary to two possible mechanisms: (a) disturbed release of ACh, which might be inhibited by cytokines, or $(b)$ receptor blockade by specific antibodies. Both mechanisms have been proposed in the pathogenesis of primary SS. ${ }^{16}$

Lymphocytes and acinar cells synthesise various cytokines (tumour necrosis factor $\alpha$, interleukin 1) which, among other effects, also inhibit ACh release from the nerve endings. ${ }^{25} 26$

The theory of antibody mediated glandular dysfunction was supported by the findings of studies in non-obese diabetic (NOD) mice as an animal model of SS. The mice developed histological changes of the salivary glands similar to those in human SS, as well as decreased salivary flow rates. ${ }^{27}{ }^{28}$ It was speculated that the glandular dysfunction in NOD mice might have developed before the lymphocytic infiltration of the glands. In Ig $\mu^{\text {null }}$ NOD mice lacking $B$ lymphocytes, the exocrine glands functioned normally despite T cell infiltration. A decrease in salivary flow, induced by transferring the sera of patients with primary SS or NOD mice with antimuscarinic antibodies to the Ig $\mu^{\text {null }}$ NOD mice, showed the importance of antibodies in evoking glandular dysfunction. ${ }^{29}$

The significance of antimuscarinic antibodies in humans was studied by several authors. Bacman et al found high levels of antibodies to M3AChR in the sera of patients with primary $(60-100 \%)$ and secondary $(\sim 80 \%)$ SS, but not in healthy controls. They also demonstrated the binding of antibodies to the second extracellular loop of protein G coupled M3AChR in the rat lachrymal and salivary glands. In an early step the antibody binding resulted in receptor activation, demonstrated by an increased action of inositol 3-phosphate and diacylglycerol activity through phospholipase C, followed by an increased intracellular $\mathrm{Ca}^{2+}$ concentration and activation of protein kinase C. Irreversible binding of the antibody to M3AChR may lead to progressive receptor blockade-probably through desensitisation, receptor internalisation, and intracellular degradation-resulting in down regulation of the exocrine secretion and emergence of clinical symptoms..$^{29-33}$

Antibodies to M3AChR may also damage the exocrine glands by the activation of inducible NO synthetase and accumulation of NO in the acinar cells, ${ }^{34}$ although the cytokine induced NO production is more feasible. ${ }^{35}$ Evidence for an increased NO concentration and confirmation of its salivary origin were reported. ${ }^{34}$

Waterman et al described the functional effects of antiM3AChR antibodies on the parasympathetic neurotransmission and smooth muscle contraction. The sera from five of the nine patients with primary SS examined inhibited rat bladder strip contractions evoked by carbachol or nerve stimulation. They confirmed the findings of Bacman et al by showing that the antibodies acted as a receptor antagonist and demonstrated inhibition of the autonomic functions. In view of the great similarity between the human and rodent muscarinic receptors, they suggested that anti-M3AChR antibodies might have the same effect in humans. Indeed, they found signs of autonomic dysfunction in three of the five patients with primary SS positive for antimuscarinic antibodies. ${ }^{16}$

\section{Intracellular signalling}

Changes have been described also on the postreceptor level-in the signal transduction. Diminished isoforms of protein kinase $\mathrm{C}$ were detected in the acinar cells, ${ }^{36}$ and the specific water channel protein aquaporin-5 accumulated basally in the cell cytoplasm rather than being transported to the apical membrane. ${ }^{37}$ A decreased fluid flow was reported in mice as a consequence of defective channel trafficking due to the absence of water channels, which are usually responsible for the rapid water transfer across the lachrymal and salivary gland cell membrane along with the paracellular water movement. ${ }^{38}$ These findings may represent the primary event in the disease process, or follow the dysfunction of muscarinic receptors, as translocation followed the stimulation of cholinergic receptors. 


\section{CONCLUSION}

In the past, sicca symptoms in primary SS were attributed solely to glandular destruction by infiltrating lymphocytes, of which $\mathrm{T}$ cells predominate. Newer findings point to an important role for cholinergic dysfunction in the disease pathogenesis, most probably mediated mainly by antimuscarinic autoantibodies. Little is known about earlier steps in the production of antimuscarinic antibodies, such as presentation of the putative autoantigen to autoreactive $\mathrm{T}$ lymphocytes and subsequent activation of B cells. Further research should provide clues to enable targeting of immune modulation and counterbalancing cholinergic dysfunction as prudent therapeutic approaches in SS.

\section{Authors' affiliations}

A Hočevar, M Tomšič, S Praprotnik, M Hojnik, T Kveder, B Rozman, Department of Rheumatology, Medical Centre Ljubliana, SI 1000 Ljubljana, Slovenia

\section{REFERENCES}

1 Fox RI, Stern M, Michelson P. Update in Sjögren's syndrome. Curr Opin Rheumatol 2000;12:391-8.

2 Jonsson R, Haga HJ, Gordon TP. Current concepts on diagnosis, autoantibodies and therapy in Siögren's syndrome. Scand J Rheumatol 2000;29:341-8

3 Vitali C, Bombardieri S, Jonsson R, Moutsopoulos HM, Alexander EL, Carsons SE, et al. Classification criteria for Siögren's syndrome: a revised version of the European criteria proposed by the

American-European Consensus Group. Ann Rheum Dis 2002;61:554-8.

4 Fox RI, Michelson P. Approaches to the treatment of Siögren's syndrome. J Rheumatol 2000;27(suppl): 15-21.

5 Andonopoulos AP, Christodoulou J, Ballas C, Bounas A, Alexopoulos D. Autonomic cardiovascular neuropathy in Siögren's syndrome. A controlled study. J Rheumatol 1998;25:2385-8.

6 Barendregt PJ, van den Bent M, van Raaij-van den Aarssen VJM, van den Meiracker AH, Vecht CJ, van der Heijde GL, et al. Involvement of peripheral nervous system in primary Siögren's syndrome. Ann Rheum Dis 2001:60:876-81.

7 Barendregt PJ, Tulen JHM, van den Meiracker AH, Markusse HM. Spectral analysis of heart rate and blood pressure variability in primary Siögren's syndrome. Ann Rheum Dis 2000;61:232-6.

8 Barendregt PJ, van den Meiracker AH, Markusse HM, Tulen JHM, Boomsma F, van der Heijde GL, et al. Parasympathetic failure does not contribute to ocular dryness in primary Siögren's syndrome. Ann Rheum Dis 1999;58:746-50

9 Kovács L, Török T, Bari F, Kéri Z, Kovács A, Makula E, et al. Impaired microvascular response to cholinergic stimuli in primary Sjögren's syndrome. Ann Rheum Dis 2000;59:48-53.

10 Greenspan JS, Daniels TE, Talal N, Sylvester RA. The histopathology of Siögren's syndrome in labial salivary gland biopsies. Oral Surg Oral Med Oral Pathol 1974;37:217-29.

11 Lindvall AM, Jonsson R. The salivary gland component of Sjögren's syndrome: an evaluation of diagnostic methods. Oral Surg Oral Med Oral Pathol 1986;62:32-42.

12 Jonsson R, Kroneld U, Bäckman K, Magnusson B, Tarkowski A. Progression of sialadenitis in Sijogren's syndrome. Br J Rheumatol 1993:32:578-81.

13 Andoh Y, Shimura S, Sawai T, Sasaki H, Takishima T, Shirato K. Morphometric analysis of secretory glands in Siögren's syndrome. Am Rev Respir Dis 1993;148:1358-62.

14 Leroy JP, Pennec YL, Soulier C, Berthelot JM, Letoux G, Youinou P. Follow up study of labial salivary gland lesions in primary Siögren's syndrome. Ann Rheum Dis 1992;51:777-80

15 Hakala $M$, Niemelä RK. Does autonomic nervous impairment have a role in pathophysiology of Siögren's syndrome. Lancet 2000;355: 1032-3.
16 Waterman SA, Gordon TP, Rischmueller M. Inhibitory effects of muscarinic receptor autoantibodies on parasympathetic neurotransmission in Siögren's syndrome. Arthritis Rheum 2000;43: 1647-54

17 Törnwall J, Konttinen YT, Hietanen J, Sorsa T, Hukkanen M. VIP in salivary glands in Siögren's syndrome. Br J Rheumatol 1995;34:891-3.

18 Fox RI, Konttinen Y, Fisher A. Use of muscarinic agonist in the treatment of Siögren's syndrome. Clin Immunol 2001;101:249-63.

19 Benarroch EE. The central autonomic network. In: Low PA. Clinical autonomic disorders. Philadelphia, Lippincott-Raven, 1997:17-22.

20 Bergdahl $\mathbf{M}$, Bergdahl J. Low unstimulated salivary flow and subjective oral dryness: association with medication, anxiety, depression and stress. J Dent Res 2000;79:1652-8.

21 Ship JA, De Carli C, Friedland RP, Baum BJ. Diminished submandibular salivary flow in dementia of the Alzheimer type. J Gerontol 1990:45:M61-6.

22 Konttinen YT, Hukkanen M, Kemppinen P, Segerberg M, Sorsa T, Malmstrom $M$, et al. Peptide containing nerves labial salivary glands in Siögren's syndrome. Arthritis Rheum 1992;30:15-20.

23 Konttinen YT, Sorsa T, Hukkanen M, Segerberg M, Kuhlefelt-Sundstrom $M$, Malmstrom $M$, et al. Topology of innervation of labial salivary glands by protein gene product 9.5 and synaptophysin immunoreactive nerves in patients with Sjögren's syndrome. J Rheumatol 1992;19:30-7.

24 Zoukhiri D, Hodges RR, Dartt DA. Lacrimal gland innervation is not altered with the onset and progression of disease in murine model of Siögren's syndrome. Clin Immunol Imunopathol 1998;89:126-33.

25 Zoukhiri D, Kublin CL. Impaired neurotransmitter release from lacrimal and salivary gland nerves of a murine model of Sjögren's syndrome. Invest Ophthalmol Vis Sci 2001;42:925-31.

26 Main C, Blennerhassett $P$, Collins MS. Human recombinant interleukin 1 beta suppresses acetylcholine release from rat myenteric plexus. Gastroenterology 1993;104:1648-54.

27 Nguyen KHT, Brayer J, Cha S, Diggs S, Yasunari U, Hilal G, et al. Evidence for antimuscarinic acetylcholine receptor antibody-mediated secretory dysfunction in NOD mice. Arthritis Rheum 2000;43:2797306.

28 Humphreys-Behr MG, Peck AB. New concepts for the development of autoimmune exocrinopathy derived from studies with the NOD mouse model. Arch Oral Biol 1999;44:S21-5.

29 Robinson CP, Brayer J, Yamachika S, Esch TR, Peck AB, Stewart CA, et al. Transfer of human serum lgG to nonobese diabetic $\lg$ inull $^{\text {mice reveals }}$ a role for autoantibodies in the loss of secretory function of exocrine tissues in Siögren's syndrome. Proc Natl Acad Sci USA 1998;95:7538-43.

30 Bacman S, Berra A, Sterin-Borda L, Borda E. Muscarinic acetylcholine receptor antibodies as a new marker of dry eye in Siögren's syndrome. Invest Ophthalmol Vis Sci 2001;42:321-7.

31 Bacman S, Sterin-Borda L, Camusso JJ, Arana R, Hubscher O, Borda E. Circulating antibodies against rat parotid $M 3$ muscarinic receptors in primary Siögren's syndrome. Clin Exp Immunol 1996;104:454-9.

32 Bacman S, Leiros Perez C, Sterin-Borda L, Hubscher O, Arana R, Borda E. Autoantibodies against lacrimal gland M3 muscarinic acetylcholine receptors in patients with primary Siögren syndrome. Invest Ophthalmol Vis Sci 1999:39:151-6.

33 Humphreys-Beher MG, Brayer J, Yamachika S, Peck AB, Jonsson R. An alternative perspective to the immune response in autoimmune exocrinopathy: induction of functional quiescence rather than destructive autoaggresion. Scand J Immunol 1999;49:7-10.

34 Bacman S, Berra A, Sterin-Borda L, Borda ES. Human primary Sjögren's syndrome autoantibodies as mediators of nitric oxide release coupled to lacrimal gland muscarinic acetylcholine receptors. Curr Eye Res $1998 ; 1136-42$

35 Konttinen YT, Platts LAM, Tuominen S, Eklund KK, Santavirta N, Törnwall J, et al. Role of nitric oxide in Siögren's syndrome. Arthritis Rheum 1997:40:875-83.

36 Törnwall J, Konttinen YT Tuominen RK, Törnwall M. Protein kinase C expression in salivary gland acinar epithelial cells in Siögren's syndrome. Lancet 1997;349:1814-15

37 Steinfeld S, Cogan E, King LS, Agre P, Kiss R. Abnormal distribution of aquaporin-5 water channel protein in salivary glands from Siögren's syndrome patients. Lab Invest 2001;81:143-7.

38 Tsubota K, Hirai S, King LS, Agre P, Ishida N. Defective cellular trafficking of lacrimal gland aquaporin-5 in Sjögren's syndrome. Lancet 2001;357:688-9. 